Biorheology 29, vii-x 1992

$0006-355 X / 92 \$ 5.00+.00$ Printed in the USA.

Copyright $\odot 1993$ Pergamon Press Ltd. All rights reserved.

\title{
ALFRED L. COPLEY, THE TEACHER AND FOUNDER
}

\section{By Siegfried Witte}

The science of medicine has always involved and still involves the phenomenon of the development of "schools." Up until approximately 25 years ago, they were formed by the fruitful ties between teacher and pupil. Today, they are often based on the phenomena of trends, tendencies, and indeed "fashions." A. L. Copley cannot be categorized as founder of a school along these two lines, although he has become a teacher to many physicians. He has developed a variety of research specialties, founded several successful journals, and created the basic framework for a world-wide extending science by founding the International Society of Hemorheology, which later on was renamed International Society of Biorheology. He is a unique and great personality who in reality comprises two different personalities, as has been revealed in a recently published book, One Man, Two Visions-L. Alcopley, A. L. Copley; Artist and Scientist; published by Pergamon Press, from which the following article quotes.

What has been my own experience with him? The study of blood clotting formed the beginning of his work as well as that of mine. While still a student, in the clinical semester at the Institute of Physiology, University of Würzburg, he had assisted Professor Wöhlisch in isolating the clotting enzyme, thrombin. About 15 years later, in the Medical Polyclinic of the same University, I too worked with clotting methods. The in vitro tests then in use did not satisfy me as a clinician. I wanted to investigate blood clotting in vivo. As a disciple of Paul Morawitz of Leipzig, my chief, Professor Norbert Henning, was interested in hematological microscopy besides clotting; I, therefore, endeavored to investigate the phenomenon of blood clotting in vivo using microscopic methods. The permeability of blood vessels of the microcirculation could be investigated in animal experiments. Fluorescent labelling of components of blood plasma proved to be especially suitable in this context. Pursuing this approach, I found in 1956 that vascular permeability was always increased when blood clotting was disturbed in terms of reduced coagulability (Witte, S., Über Beziehungen zwischen Blutgerinnung und Capillarpermeabilität. Habil. schr. Erlangen 1958; Fol. haemat. N. F. 1, 320-338, 1957; Z. ges. exp. Med. 129, 181-192; 358-367, 1957; Thromb. Diath. haem. 2, 146-169, 1958).

In the discussion of these findings I have quoted $\mathrm{Al}$ 's lecture, "Thrombosis and Thrombo-Embolism in Blood Capillaries," which I heard during the International Conference on Thrombosis and Embolism in Basel in 1954. There, he suggested that the "so-called endocapillary layer of the endothelium may be identical with non-gelated fibrin" ((1955). Thrombosis and Embolism. Th. Koller, W. R. Merz, Eds., Benno Schwabe, Basel, 452-457). His idea that "fibrin is a constituent of the interendothelial cement or of an endothelial coating contributing to the integrity of the wall of blood vessels" ((1953). XIXth Internat. Physiol. Congr., Montreal, Abstr. of Commun., p. 280) was based on the results that capillary petechiae can be induced by a local application of plasmin, carried out with the method of the nictitating membrane of the rabbit's eye, developed by him, together with $\mathrm{R}$. Chambers.

In this way, a research direction was built up which led to many new fields of research and has become of far-reaching importance for clinical medicine. I can only give a very subjective and incomplete view of these developments. 
My first personal scientific contact with Al Copley was at the European Congress of Hematology in 1957 in Copenhagen. Al made some very kind remarks in the discussion following my paper on immunothrombocytopenia using capillary microscopy and on my poster on the use of fluorescence microscopy in the study of capillary permeability. Our next meeting was at the International Congress of Hematology in Rome in 1958. There $\mathrm{Al}$ introduced an entirely new field of research in conjunction with his concept of the physiological role of fibrin in the surface plasma zone of the vascular intima attached to the capillary wall by viscous interaction in flow. He called the new field "hemorheology" (Copley, A. L., The rheology of blood. A survey. XXVth annivers. meet. Amer. Inst. Physics, Chicago, Illinois, 1951; J. Colloid S. 7, 323-333, 1952; Vascular integrity and the endoendothelial fibrin film. 8th Congr. Hematol., Wien, 1961, Abstr. p. 45, S. Karger, Basel, New York, 1962, No. 357, 1-20).

He discovered the capacity of a fibrin-coated artificial surface to increase the flow rate of blood (Copley, A. L. (1958). Adherence and viscosity of blood contacting foreign surfaces and the plasmatic zone in blood circulation. Nature (Lond.) 181, 551552). George Scott Blair was very interested in Copley's findings, which led soon after to combined studies and several publications. This phenomenon was later named the Copley-Scott Blair effect by Oka (Oka, S. (1981). Copley-Scott Blair phenomenon and electric double layer. Biorheology 18, 347-353). It opened the new field of hemorheology. At the same congress, I reported on blood clotting in the interstitial fluid (Witte, S., Bressel, D. (1958). Die Blutgerinnung in der interstitiellen Flüssigkeit. Proc. VIIth Internat. Congr. Hematol. Rome. Il Pensiero Scientif. Roma, Vol. II, 1-3), an observation that inspired Copley to coin the term "perihemorheology," first proposed by him as "parahemorheology" ((1988). Clin. Hemorheol. 5, 769) and replaced by the new and more adequate term, "perihemorheology" ((1987). Clin. Hemorheol. 7, 377-378). At that time, $\mathrm{Al}$ was working in London. In 1959, on the occasion of the 7th European Congress of Hematology, he gave a big party there at his home. This he organized with his usual great charm and enthusiasm, together with his delightful and charming wife, the Icelandic artist, Nina Tryggvadottir. In 1960 he moved back to New York.

The importance of the basement membrane and fibrinolysis for the integrity of capillaries was discussed by $\mathrm{Al}$ in a lecture at the European Congress of Hematology in 1961 in Vienna ((1962). Vascular integrity and the endoendothelial fibrin film. 8th Congr. Haematol., Vienna, 1961. S. Karger, Basel, New York). Previous to this, at the First European Conference on Microcirculation in 1960 in Hamburg, Knisely and Fåraeus had engaged in a vehement discussion of the rheological observations they designated as "blood sludge" and hemagglutination (Europ. Conf. Microcirculation. (1961). H. Harders, Ed., Bibl. anatom. 1. S. Karger, Basel, New York). This had resulted in a greatly increased interest in the phenomena of microcirculation and Al's lecture fell on very fertile ground. Hence, at the Second European Conference on Microcirculation in 1962 in Pavia, Al was asked to present the introductory paper, on "Capillary Permeability versus Fragility and the significance of Fibrin as a Physiological Cement of the Blood Vessel Wall" ((1964). Bibl. anat. 4, 3-19, S. Karger, Basel, New York). He presented further experimental findings on this topic at the Third European Conference on Microcirculation in Jerusalem ((1965). Capillary permeability, capillary incontinence, compaction stasis, and basement membrane breakdown. Bibl. anat. 7, 148-155) and at the International Congress of Hematology in Stockholm (Copley, A. L., Luchini, B. W., Perdamo, J. ((1964). On basement membrane breakdown and capillary hemorrhage produced by collagenase and elastase. Xth Congr. Internat. Soc. Haematol., Stockholm, $0,23)$, both in 1964 .

The Fourth International Congress of Rheology held at Brown University, Providence, Rhode Island in 1963 was a highlight in the life of Al. Here, he organized a Symposium on Biorheology. With the assistance of the U.S. Navy he gathered together participants who to this day constitute the research elite in biorheology. The proceedings of the Congress were printed in four parts by John Wiley in 1965. Part 4, edited by Al, is 
the source from which current topics and schools of biorheology all derive their origin. With his own work, Al took a modest back seat ((1965). Symposium on Biorheology, A. L. Copley, Ed. Intersc. Publ., New York, London, Sydney).

Another important year for Al was 1966. Immediately after the Fourth European Conference on Microcirculation held early in July in Cambridge, England, where he reported on the permeability-enhancing effect of fibrinopeptides ((1967). Copley, A.L., Hanig, J. P., Luchini, B. W., Allen, R., Jr. On the capillary permeability-enhancing activity of isolated fibrinopeptides and their role in the physiology of the blood capillary wall. Bibl. anat. 9, 475-481. S. Karger, Basel, New York), the First International Conference on Hemorheology took place in Reykjavik, organized by $\mathrm{Al}$ (Copley, A. L., Ed., Hemorheology Proc. 1st Internat. Conference, Univ. of Iceland, 1966; Pergamon Press, Oxford, New York, 1968). On this memorable occasion and in impressive surroundings, the International Society of Hemorheology was founded. Al was elected its president; I became treasurer and collected the first membership contributions (in Icelandic currency).

With this event in Iceland, the triumphant progress of biorheology in clinical medicine based on a sound theoretical and experimental basis started to take off in earnest. Pergamon Press, through its founder and publisher, Mr. Robert Maxwell, also played a major role in the propagation of biorheology in the world of science. It started with the publication of a proceedings volume in 1960 entitled Flow Properties of Blood and Other Biological Systems, edited by A. L. Copley and G. Stainsby. This volume contained the lectures presented at a meeting, organized by $\mathrm{Al}$, and convened in Oxford, England in 1959. An immediate consequence was Robert Maxwell's invitation to George Scott Blair and Al Copley to found and edit a journal, Biorheology, with Pergamon Press. The first issue appeared in 1962. In 1980, Clinical Hemorheology was founded as a companion journal with $\mathrm{Al}$ and myself as Editors-in-Chief. The International Society of Hemorheology founded in Iceland was renamed in 1969 The International Society of Biorheology. This occurred in Heidelberg on the occasion of the Second International Conference on Hemorheology ((1971). Hartert, H. H., Copley, A. L., Eds., Theoretical and Clinical Hemorheology. Springer-Verlag, Berlin, Heidelberg, New York). Here, A. L. Copley and his co-workers presented new results on fibrin gelation using the techniques of light scattering and rheogoniometry ((1971). Copley, A. L., Devi, A., King, R. G., Scheinthal, B. M., Ohlmeyer, P. Gelation of fibrinogen and plasma systems studied by light scattering and rheogoniometric methods. In: Theoretical and Clinical Hemorheology. H. H. Hartert, A. L. Copley, Eds., Springer-Verlag, Berlin, Heidelberg, New York, 154-164). At this conference, $\mathrm{Al}$ received the degree of Dr. med. honoris causa from the Medizinische Fakultät, Ruprecht-Karl-Universität Heidelberg.

The pathophysiological aspects of blood clotting clearly have impacts on the field of thrombogenesis and it was typical for Al to conclude in 1972 that he should found a new journal, Thrombosis Research. It was the same year that the First International Congress of Biorheology took place in Lyon. These three Pergamon Press journals initiated by $\mathrm{Al}$, as well as the international congresses in hematology, biorheology, and microcirculation became fertile fora for the presentation and discussion of his ideas and findings in the years that followed.

At the World Conference of the European Society of Microcirculation in Antwerp in 1976, I demonstrated vital experimental microscopy findings with fluorescent-labeled fibrinogen that showed an affinity of fibrinogen for the capillary wall in situ and thus supported Al's hypothesis of the existence of an endoendothelial fibrin(ogen) lining (EEFL) in vivo ((1977). Witte, S., Zenzes-Geprägs, S. The affinity of fibrinogen to the vessel wall as proved in situ. Bibl. anat. 16, 279-281). Al compiled further findings and arguments on the EEFL, on fibrinogen clotting and on the interface between the two portions of the "vessel-blood organ" and printed these in the first number of Clinical Hemorheology in 1981 ((1981). Copley, A. L. Hemorheological aspects of the endoendothelial fibrin lining and of fibrinogen gel clotting. Their importance in 
physiological and pathological conditions. Clin. Hemorheol. 1, 9-72). He summarized his ideas in a paper presented at the Satellite Symposium of the Third International Congress in Cell Biology in Tokyo. This paper (Endoendothelial fibrin (ogenin) lining: The interface between the two portions of the "vessel-blood organ") was published in the proceedings of the meeting, Glomerular Dysfunction and Biopathology of the Vascular Wall ((1985). Seno, S., Copley, A. L., Venkatachalam, M. A., Hamashima, Y., Tsujii, T., Eds., Academic Press, Tokyo, Orlando, San Diego, New York, Austin, Boston, London, Sydney, Toronto, pp. 59-86).

The fact that his concepts were increasingly taken notice of, discussed and accepted was shown impressively by a Symposium on the Endo-Endothelial Fibrin Lining held at the Twelfth European Conference on Microcirculation in Jerusalem in 1982 ((1983). Copley, A. L., Ed., The endoendothelial fibrin lining. Thromb. Res. Suppl. V), by the International Conference on Surface Phenomena in Hemorheology of the New York Academy of Sciences, which he organized in New York in 1982 ((1983). Copley, A. L., Seaman, G. V. F., Eds., Surface phenomena in hemorheology: Their theoretical, experimental, and clinical aspects. Ann. N. Y. Acad. Sci. 416), and by a Symposium on Permeability and the Blood-Vessel Wall held at the Fifth International Congress of Biorheology in Baden-Baden in 1983 ((1984). Silberberg, A., Wayland, H., Eds., Permeability and the blood vessel wall. Biorheology 21, Nos. 1\&2).

The history of clinical hemorheology was outlined by $\mathrm{Al}$ in a plenary lecture at the Fourth European Conference on Clinical Hemorheology in Siena in 1985 ((1985). Copley, A. L. The history of clinical hemorheology. Clin. Hemorheol. 5, 765-811). At this meeting he also presented a look into the future. In particular, he drew attention to the field of perihemorheology which is linked to the "vessel-blood organ" by the processes of transcapillary transport.

A. L. Copley is and will remain a teacher of medicine. His pupils are and will be working on the most diverse aspects of theoretical and practical medicine. They will themselves become teachers; perhaps they will found schools. Al's message is and will be spreading. 